Brit. J. industr. Med., 1950, 7, 117.

\title{
HISTOLOGICAL STUDIES OF THE EFFECTS OF BERYLLIUM OXIDE (GLUCINE) ON ANIMAL TISSUES
}

\author{
BY \\ A. POLICARD
}

From the Faculté de Médecine de Lyon

(RECEIVED FOR PUBLICATION MARCH 22, 1950)

The toxic action of beryllium eompounds has been studied extensively in the last few years. In many such compounds the harmful effect is due to the anion. An example is seen in the case of the double fluoride of sodium and beryllium which is often used in industry. However it is quite certain that the action of such compounds has an action of its own which was observed long ago (Siem, 1886; Comar, 1935). Its specific effect seems to be on the histiocytes (reticulo-endothelial system), the beryllium ion causing hyperplasia and hypertrophy of these cells thus leading to the granulomata so characteristic of berylliosis. I have lately carried out histological investigations into that property of beryllium to try to establish more precisely the action of beryllium oxide as it is used in the electrometallurgical preparation of beryllium alloys. The researches concerned the reaction of subcutaneous connective tissue and the cells of the peritoneum and lung to dusts of beryllium compounds.

\section{Experimental Method}

The beryllium oxide used came from a hydroelectric plant in Savoy. It was of two types, the first being that commonly used in the preparation of alloys. It had traces of fluoride and tended to cause some necrosis in the surrounding cells and tissues. There was a second type, which had been specially prepared and freed from all traces of fluoride. It caused no noticeable necrosis, a fact which stresses the importance in industrial toxicology of impurities in the substances under investigation. The dusts of beryllium oxide consisted of minute particles less than one micron in diameter. Such particles agglutinate very readily and form rather regular spherical masses some 15 to $30 \mu$ across. It is clusters of this type that are seen in the tissues where injections have been made.

One of the difficulties encountered was the histochemical demonstration of beryllium oxide.
Denz (1949) suggested the use of naphthochrome green $B$, which stains beryllium green. As I could not secure this dye, I had to use another technique. Beryllium oxide adsorbs aniline dyes very readily, just as aluminium or magnesium oxides do. When histological preparations are treated with van Gieson stain, beryllium oxide is stained a brilliant red. Since collagen fibres also take the colour, it becomes necessary to distinguish them from the beryllium oxide. This can easily be done in polarized light when the collagen fibres are seen to be doubly refractile, whereas the beryllium oxide masses are not. The findings can be further confirmed by using micro-incineration : marked deposits of ash are left where deposits of beryllium oxide have been.

The histological methods used were of the usual classical type (haemalum eosin orange). Guineapigs and white rats were the experimental animals. Beryllium oxide dusts were introduced in the following ways.

Lung.-By rotation dusting (Policard), a somewhat rough and ready method, but quick and effective ; by intratracheal injection (after Kettle) ; and by intranasal injection in deeply anæsthetised animals who had lost their reflexes.

Subcutaneous Tissues.-Injection of suspensions at the nape of the neck.

Peritoneum.-Injection of $2 \mathrm{ml}$. of a suspension in saline.

\section{Results}

The principal findings of the research can be classified as follows :

Distribution of Particles of Beryllium Oxide.Whether in subcutaneous or pulmonary tissue or in the peritoneum, the particles of beryllium oxide never appear isolated but always agglutinated as spherical masses. One can vaguely make out the initial particles in such clusters, more readily during the first few days than after a week. There is a 
thin space which stains readily round the cluster and bounds it (Fig. 1). This boundary is often folded (Fig. 2). It seems to be a protein adsorption
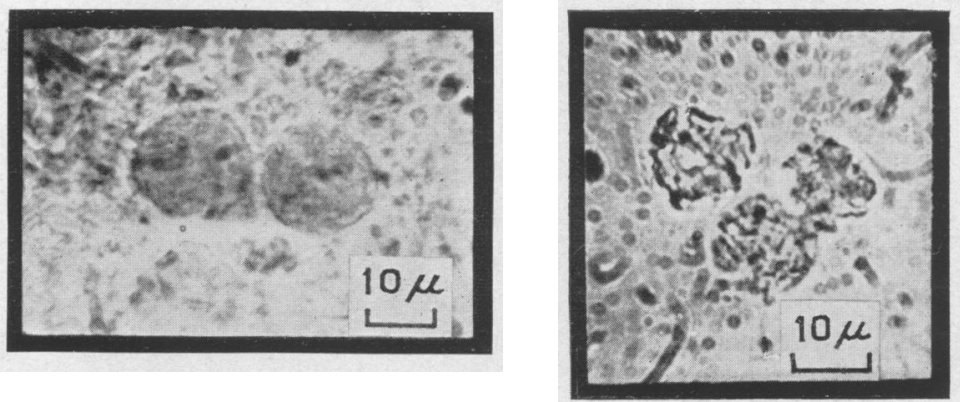

Fig. 1.-Peritoneum of rat showing two clusters of particles of beryllium oxide (type containing traces of fluoride). Necrosis of the neighbouring tissue. deposit. It disappears after micro-incineration. In contrast that procedure shows up more clearly the individual particles of beryllium oxide.

In the lungs one sees massive clusters in the bronchioles: the latter are completely obliterated in some cases, the epithelium being in direct contact with the beryllium oxide (Fig. 3). In the lung parenchyma one may observe, but only rarely, masses of particles 10 to $30 \mu$ across, mostly in the alveolar canals, and only very rarely in the alveoli. After three to four weeks the clusters seem to be shrinking ; they look wrinkled, with an irregular surface; in other fields one may find some which seem to be breaking up.

showing beryllium oxide with crinkled surface.

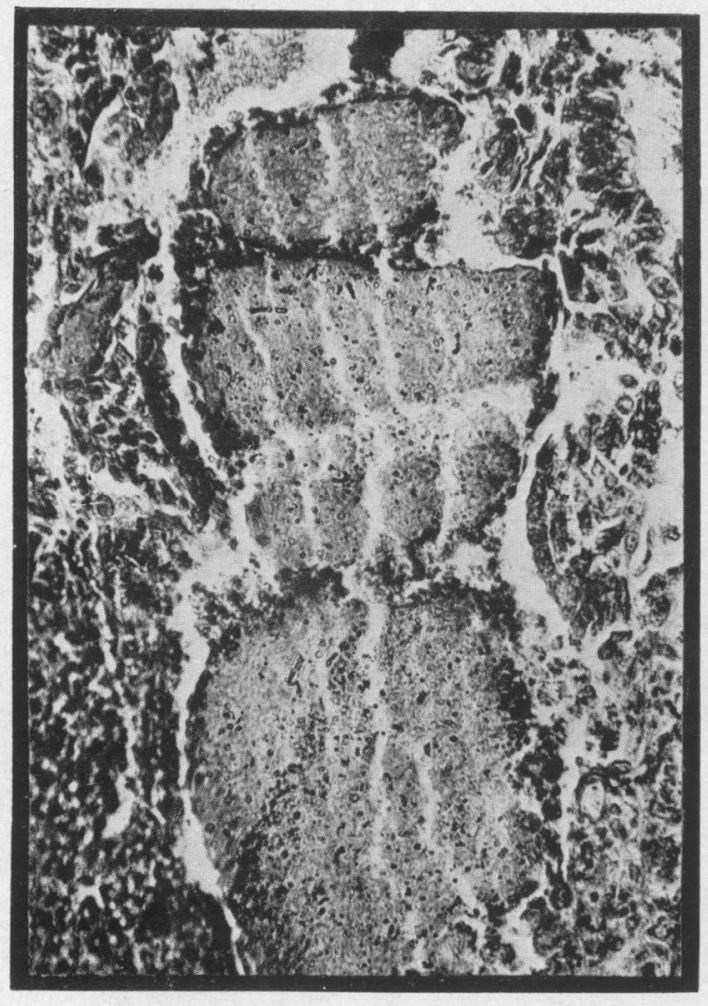

FIG. 3.--L ung of guinea-pig showing mass of beryllium oxide free from traces of fluoride in the bronchiole 23 days after intratracheal injection. No necrosis of neighbouring tissue. Some cells are closely applied to the border of the mass. $(\times 200$. $)$
Initial Reaction of Tissue Close to the Particles.Two conditions may prevail amongst cells in contact with a cluster of particles of beryllium oxide.

(1) If the beryllium oxide is free of fluoride the cells show no great change; the nuclei take the dye well and look normal. The histiocytes cling closely to the clusters which appear to be superficially phagocytosed and intracellular. Careful observation, however, shows the boundary which was described earlier between the histiocyte and the cluster (Fig. 4). In the bronchioles the epithelial cells lining the central mass of beryllium oxide show no sign of marked alteration. The ciliated lining, however, is gone, and the epithelium seems somewhat flattened.

(2) When the beryllium oxide has not been freed of fluoride things are different. The cells, whether histiocytic or epithelial, are definitely necrotic. The nuclei do not take the stain. The normal structure

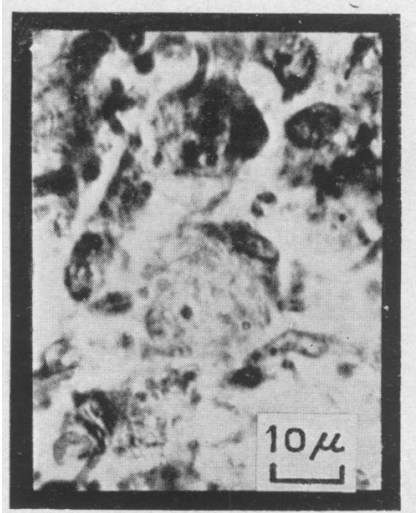

Fig. 4.-Peritoneum of guineapig showing beryllium oxide mass free from fluoride in an alveolar canal. Histiocytes flattened on the surface. $(\times 200$. 
of protoplasm has disappeared and is replaced by a granular detritus.

The necrosing action of beryllium oxide contaminated with fluoride is extremely clear when injections are made into the peritoneum. There is violent irritative peritonitis which very often causes the death of the animal. Such is not the case where the beryllium oxide is fluoride-free. By its irritant effect the fluoride brings about foci of chemical œdema when it is applied to the parenchyma of the lung. This may be generalized, affecting several lobes, and may precipitate death in a few days. The effect is similar to that produced by the double fluoride of sodium and beryllium, but less intense (Policard, 1949).

Reactions of Cells and Tissues within Specific Radius.-Cells and tissues within a radius of 3 to $400 \mu$ of a cluster of beryllium oxide show specific reactions. The fibroblasts are hypertrophied, but not multiplied. Round the capillaries there is neither congestion nor any marked change in the endothelium. On the other hand the perithelial cells are clearly hypertrophied. The most marked changes affect the histiocytes. They are increased both in number and in size. Some are very large indeed, up to 40 to $50 \mu$ in diameter, with somewhat irregular nuclei measuring 25 to $30 \mu$ often with large nucleoli. One can see neither giant cells nor polymorphonuclear cells nor congestion nor definite œdema. The reaction is a purely histiocytic one.

Beryllium oxide which contains traces of fluoride causes, as stated previously, a local necrosis. This brings about a local inflammatory reaction with œdema and polynuclear invasion. The polynuclear cells die locally and form no pus. It goes without saying that the intraperitoneal injections were aseptic. This reaction on the part of the histiocytes leads to the formation of the beryllium granulomata.

Histiocytic Reaction and Formation of Beryllium Granulomata.-The histiocytic hyperplasia caused by the presence of the beryllium oxide clusters brings about the formation of granulomata. They are particularly typical in the lung parenchyma, though why that should be so is not quite clear.

The histiocytes crowd the alveolar cavity in a territory some 0.5 to 0.8 of a millimetre across (Fig. 5). In some cases, more especially in the rat, the accumulation of histiocytes looks rather like a marked thickening of the walls of the alveoli than like a nodular granuloma. But the cell types are the same in either case. These hypertrophied histiocytes are large cells sometimes 30 to $40 \mu$ in diameter. Their nuclei are very voluminous $(20$ to $25 \mu)$, irregular and wrinkled and show abundant

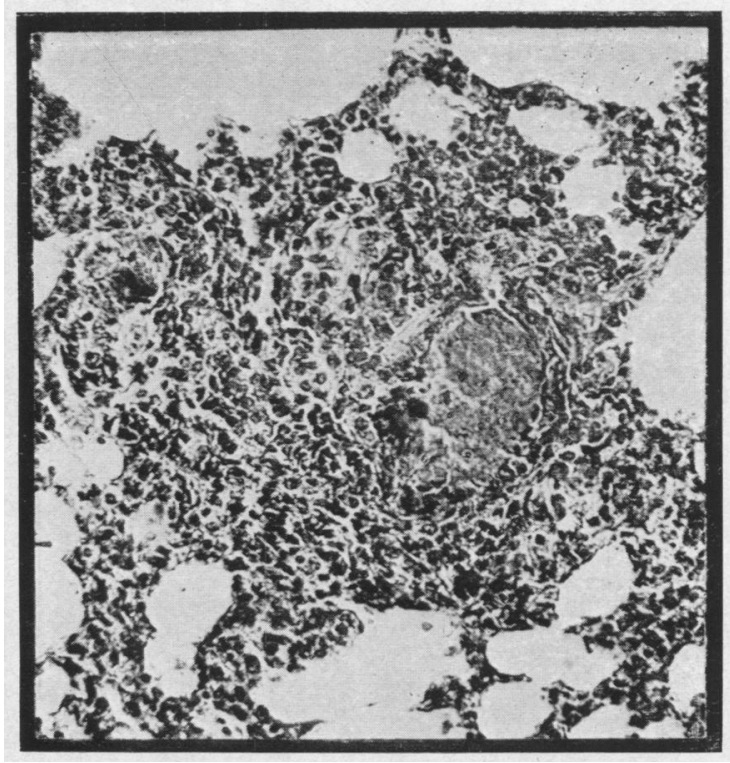

FIG. 5.-Guinea-pig 23 days after intratracheal injection, showing the granulomatous reaction round a cluster of beryllium oxide free from fluoride. $(\times 200$. $)$

chromatin and several large nucleoli (Fig. 6). Such beryllium granulomata have often been described; my observations confirm those of previous authors. They do not remain in the same histological state constantly. After three to six weeks they undergo

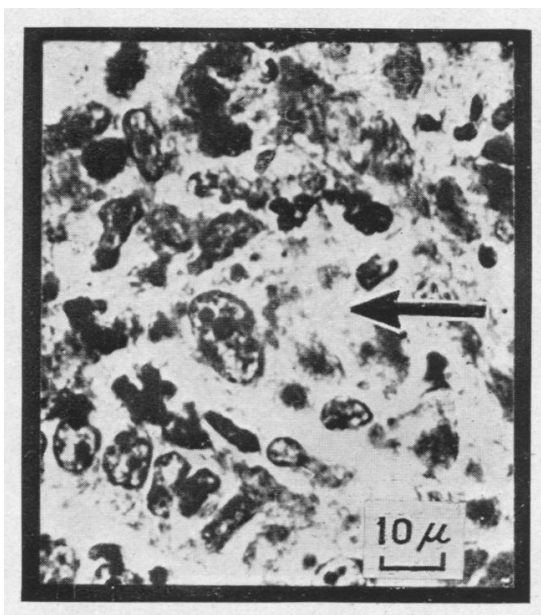

FIG. 6.-Lung of guinea-pig after intratracheal injection, showing hypertrophied histiocyte, cytoplasm poorly defined, and fairly large areas containing beryllium oxide staining with Ponceau red. 
various fates which all lead to the same result, the disappearance of the granuloma. I have described their various forms of evolution in previous papers (Policard, 1949a, and 1949b). Briefly they are as follows: (1) Progressive fibrosis with ultimate formation of a small fibrous nodule ; (2) transformation of the intra-alveolar cells into "foam cells" ultimately degenerating and freeing the alveoli which become permeable to air once more ; and (3) invasion of the cell mass of the granuloma by cells arising like buds from the neighbouring bronchioles with the formation of curious small bronchiolar adenomatous masses.

Why a granuloma should follow one course rather than another is still to be determined. Equally unexplained is the observation that such granulomata, which are very characteristic in the lung and subcutaneous tissue, are far less distinct when injections are made intraperitoneally.

Mode of Resorption of Beryllium Oxide Masses.-In contrast with what happens to particles of coal or silica, those of beryllium oxide are ultimately absorbed and eliminated. These are slow processes. Ten months after injection one may still encounter clusters of beryllium oxide at the point of injection. But they are definitely smaller, as if shrunken.

The morphology of the process is as follows. In the bronchioles a clear space appears, apparently filled with liquid and mucus, between the epithelium and the mass of beryllium oxide which obstructs the lumen. The cluster is set free and bodily evacuated along the bronchus, probably by coughing (Fig. 7). The clusters of beryllium oxide in the alveoli gradually become scattered and their substance absorbed by the neighbouring histiocytes. These elements then take on curious shapes which show well with van Gieson stain. In the cytoplasm of these hypertrophied cells are seen diffuse globules measuring some 2 to $6 \mu$ which take the stain like the beryllium oxide in the clusters (Fig. 6). Though one could not state definitely that these fragments consist of beryllium oxide, it seems likely that they contain it in conjunction with some protein substratum. We are carrying out cytological work on those singular beryllium cells.

And what becomes of the beryllium oxide thus absorbed ? That can hardly be decided precisely at present. Ultimately it seems to be eliminated by the kidney or stored by the liver. It has indeed been possible to demonstrate by spectrographic analysis the presence of beryllium oxide in those

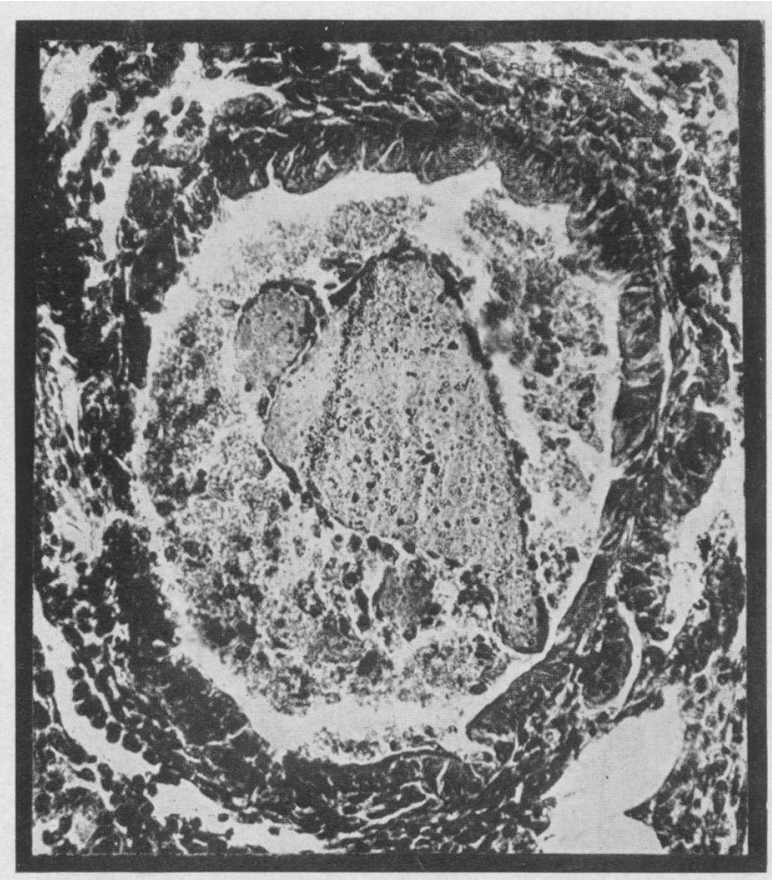

FIG. 7.-Guinea-pig lung after intratracheal injection, showing the elimination of an intra-bronchiolar mass of beryllium oxide free from fluoride. A mass of mucus and desquamated cells is shown surrounding the beryllium oxide cluster.

two organs. But the stages intervening between the histiocytic cell containing beryllium masses and the kidney or liver are still uncharted.

\section{Discussion}

The data described above allow of the following considerations. It is a striking fact that beryllium oxide when freed from fluoride has no necrosing effect on either epithelial or connective tissue cells which come in contact with it. It is impossible to state categorically that beryllium oxide has no effect whatsoever and that the cells in contact with it remain absolutely normal. But it is certain that whatever action it has is very slight ; the normal aspect of the cells is hardly altered. When beryllium oxide contains traces of fluoride, as is the case in the industrial product used, things are different. Those traces become hydrolysed in the tissues and the hydrofluoric acid produced has its well-known action. The mechanism is commonplace. On the other hand beryllium oxide, even when free of fluoride, has a stimulating action on histiocytes. For some distance about its particles the histiocytes show hyperplasia and hypertrophy of a most curious type. This leads to the formation of granulomata 
which are characteristic of chronic and subacute beryllium lesions. Although the detailed mechanism of that reaction is still unknown, its reality seems beyond doubt. Comar (1935), in an excellent thesis, which is not generally quoted, concluded that beryllium exerted a stimulating action on the reticulo-endothelial system. Our observations confirm his conclusions.

Where the mode of action itself is concerned the following facts are of some importance. One knows from the work of Klemperer, Miller, and Hill (1949); Grier, Hood, and Hoagland (1949); DuBois, Cochran, and Mazur (1949), and others, that beryllium compounds can block the phosphatases and therefore compete with magnesium ions. It would be most interesting to follow up this train of thought.

\section{Summary}

Injections into animal tissues of pure beryllium oxide provoke hyperplasia and hypertrophy of histiocytes. When commercial beryllium oxide is used the effect is much more toxic and necrosis of cells occurs. This is not due to beryllium, but to hydrofluoric acid produced by hydrolysis when traces of fluorides come into contact with moist tissues.

The action on the histiocytes occurs over a small area of about 1 millimetre diameter. It leads to the formation of the well-known beryllium granuloma. Deposits of beryllium oxide in the tissues are slowly eliminated. One method of elimination is by the histiocytes themselves although the mechanism of this is not understood. Beryllium oxide was demonstrated in phagocytic cells by histological methods.

I wish to thank M. Pruvot of the Usines A.F.C. at St. Jean de Maurienne (Savoie) for his help and advice. I am indebted to Dr. M. E. F. Hunter for the English translation of this paper.

\section{REFERENCES}

Comar, M. (1935). "De la toxicité du beryllium-glucinium." Thesis, Paris.

Denz, F. A. (1949). Quart. J. micr. Sci., 90, 317.

DuBois, K. P., Cochran, K. W., and Mazur, M. (1949). Science, 110,420

Grier, R. S., Hood, M. B., and Hoagland, M. B. (1949). J. biol. Chem., 180, 289 .

Klemperer, F. W., Miller, J. M., and Hill, C. J. (1949). Ibid. $180,281$.

Policard, A. (1949a). Bull. Acad. nat. Méd., Paris, 133, 581.

(1949b). J. franc. Med. Chir. thorac., 3, 501.

Siem, P. (1886). "Ueber die Wirkung des Aluminiums und des Berylliums auf den thierischen Organismus." Inaug. diss., 